\title{
Editorial
}

\section{Human interactions and research developments}

This editorial aims to recognize the valuable contribution of the researchers who have devoted a great contribution to the European Journal of Management and Business Economics (EJM\&BE). The academic knowledge is driven by a rich ecosystem based on authors' contributions improved by comments and suggestions from the editorial board members, reviewers and associate editors. The increasing impact factor of $E J M \& B E$ such as CiteScoreTracker of 2.95 (updated on February 6th, 2020), shows their quality and commitment. The following comments are addressed to recognize researchers who have contributed in different ways to such achievement.

Last December, Rodolfo Vázquez Casielles Professor of Marketing at the University of Oviedo passed away unexpectedly. He was a Member of the Editorial Advisory Board of $E J M \& B E$ and showed a high commitment as an advisor and as a reviewer. His valuable human dimension was transferred in his reviews to the authors. He was always on time and looking for the helpfulness. He also made me comments about the future of publishing and the coming milestones of the $E J M \& B E$. Our enormous gratitude, affect and memories are our return on his valuable human contribution to the academy. His papers on market orientation, service recovery, and service quality, to name a few, are showing his research interests. He was also close to others, offering quality in his reviews and looking for improving the quality of the papers reviewed. Rodolfo, your legacy is still knocking the doors of numerous researchers and will remain strongly connected in our minds.

$E J M \& B E$ wishes to recognize the invisible role of reviewers. Starting in 2018 the Annual Distinguished Reviewer Award of $E J M \& B E$ is based on computing the quality of the review as rated by the associate editor (50 percent), the timeliness in reviewing (40 percent) and the number of papers reviewed in 2018 (10 percent). In this first edition, Reyes Gonzalez-Ramirez Professor of Management from the University of Alicante completed four reviews with high-quality standards and timeliness. She chairs the Research Group Information Systems and Human Resources in Organizations of the University of Alicante. Her active research activity in publishing in international journals and research projects is fueling her valuable reviews to manuscripts under review. Congratulations on this award. More than deserved.

The 2018 Best Paper Award published in 2018 is based on the number of citations up to September 30th, 2019. In this edition, the awarded paper is titled Effects of the intensity of use of social media on brand equity: an empirical study in a tourist destination, authored by Igor Stojanovic, Luisa Andreu and Rafael Currás-Pérez from the Department of Marketing and Market Research of the University of Valencia. This paper published in Volume 27 Number 1, 2018 received six citations from both Scopus and ESCI databases. The paper found a positive effect on the intensity of social media use on brand awareness. Results also suggest that brand awareness influences other

(c) Enrique Bigne. Published in European Journal of Management and Business Economics. Published by Emerald Publishing Limited. This article is published under the Creative Commons Attribution (CC BY 4.0) licence. Anyone may reproduce, distribute, translate and create derivative works of this article (for both commercial and non-commercial purposes), subject to full attribution to the original publication and authors. The full terms of this licence may be seen at http://creativecommons.org/ licences/by/4.0/legalcode

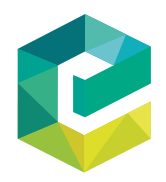

European Journal of Management and Business Economics Vol. 29 No. 1, 2020

Emerald Publishing Limited e-2444-849 p-2444-845 DOI 10.1108/EJMBE-03-2020-141 
EJMBE

29,1 dimensions of brand equity and highlight the influence of the destination affective image on the intention to make word of mouth communication. Congratulations to the distinguished authors by their valuable paper.

Enrique Bigne

2 